\title{
A community-acquired Legionnaires' disease outbreak caused by Legionella pneumophila serogroup 2: an uncommon event, Italy, August to October 2018
}

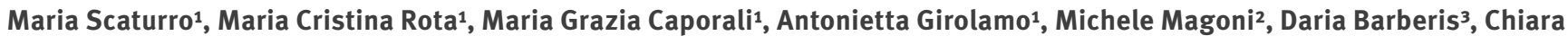
Romano $^{3}$, Danilo Cereda4, Maria Gramegna ${ }^{4}$, Antonio Piro5, Silvia Corbellini ${ }^{6}$, Cinzia Giagulli, Giovanni Rezza ${ }^{8}$, Arnaldo Caruso, Maria Luisa Ricci1

1. Department Infectious Diseases, Istituto Superiore di Sanità, Rome, Italy

2. Agency for Health Protection of Metropolitan Area of Milan, Milan, Italy

3. Public Health Laboratory, Agency for Health Protection of Brescia, Brescia, Italy

4. Public Health Managment of Welfare, Lombardy Region, Milan, Italy

5. Agency for Health Protection of Valpadana, Mantova, Italy

6. Microbiology and Virology unit, Spedali Civili Brescia Hospital, Brescia, Italy

7. Department of Molecular and Translational Medicine, Microbiology unit, University of Brescia, Brescia, Italy

8. Department of Health Prevention, Ministery of Health, Ministry of Health, Rome, Italy

9. Department of Experimental and Applied Medicine, Section of Microbiology, Spedali Civili Hospital, Brescia, Italy

Correspondence: Maria Luisa Riccii (marialuisa.ricci@iss.it)

Citation style for this article:

Scaturro Maria, Rota Maria Cristina, Caporali Maria Grazia, Girolamo Antonietta, Magoni Michele, Barberis Daria, Romano Chiara, Cereda Danilo, Gramegna Maria, Piro Antonio, Corbellini Silvia, Giagulli Cinzia, Rezza Giovanni, Caruso Arnaldo, Ricci Maria Luisa. A community-acquired Legionnaires' disease outbreak caused by Legionella pneumophila serogroup 2: an uncommon event, Italy, August to October 2018. Euro Surveill. 2021;26(25):pii=2001961. https://doi.org/10.2807/15607917.ES.2021.26.25.2001961

Article submitted on 16 Nov 2020 / accepted on 12 Apr 2021 / published on 24 June 2021

In September 2018 in Brescia province, northern Italy, an outbreak of Legionnaires' disease (LD) caused by Legionella pneumophila serogroup 2 (Lp2) occurred. The 33 cases (two fatal) resided in seven municipalities along the Chiese river. All cases were negative by urinary antigen test (UAT) and most were diagnosed by real-time PCR and serology. In only three cases, respiratory sample cultures were positive, and Lp2 was identified and typed as sequence type (ST)1455. In another three cases, nested sequence-based typing was directly applied to respiratory samples, which provided allelic profiles highly similar to ST1455. An environmental investigation was undertaken immediately and water samples were collected from private homes, municipal water systems, cooling towers and the river. Overall, 533 environmental water samples were analysed and 34 were positive for $L p$. Of these, only three samples, all collected from the Chiese river, were Lp2 ST1455. If and how the river water could have been aerosolised causing the LD cases remains unexplained. This outbreak, the first to our knowledge caused by $L p 2$, highlights the limits of UAT for LD diagnosis, underlining the importance of adopting multiple tests to ensure that serogroups other than serogroup 1, as well as other Legionella species, are identified.

\section{Background}

The first large outbreak of Legionnaires' disease (LD) was identified in Philadelphia in 1976. Since this event, a large number of outbreaks and sporadic cases have been reported, mainly caused by Legionella pneumophila serogroup 1 ( $L p 1)$ [1-4]. Indeed, $L p 1$ is the main cause of LD worldwide and is responsible for over $80 \%$ and $70 \%$ of laboratory-confirmed legionellosis cases in Europe and United States, respectively, although other species may also infect humans $[5,6]$. For example, in New Zealand and Scotland, Legionella longbeachae represents a key threat to human health, causing $30-55 \%$ of LD cases [5]. In 2019, in Europe, incidence of LD cases was 2.2 per 100,000 inhabitants, showing an increasing trend compared with previous years [6]. According to the European Centre for Disease Prevention and Control (ECDC) Surveillance Atlas of Infectious Disease, Italy was the country in the European Union (EU) in 2019 that reported the highest number of LD cases $(3,143)$ and was second in incidence, after Slovenia [7].

Outbreaks of non-Lp1 serogroups have been rarely documented. These serogroups are widespread in all man-made water systems; they mainly cause sporadic cases and are often responsible for hospitalassociated cases [8-13]. Since the beginning of epidemiological surveillance in Italy in 1983, few sporadic LD cases caused by non-Lp1 serogroups have been reported [14]. According to the EU case definition, laboratory criteria for LD case confirmation must include at least one of the following three: (i) isolation of Legionella spp. from respiratory secretions or any normally sterile site, (ii) detection of $L p$ antigen in urine, (iii) a significant rise in specific antibody level to $L p 1$ in paired serum samples [15]. Currently, 
Cases and incidence rate of Legionnaires' disease cases per million inhabitants, Brescia province, Italy, 2015-2018

\begin{tabular}{|c|c|c|c|c|c|c|c|c|c|}
\hline \multirow[b]{2}{*}{ Area } & \multirow[b]{2}{*}{ Population } & \multicolumn{2}{|c|}{2015} & \multicolumn{2}{|r|}{2016} & \multicolumn{2}{|r|}{2017} & \multicolumn{2}{|r|}{2018} \\
\hline & & Cases & 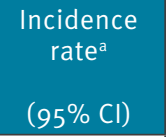 & Cases & $\begin{array}{c}\text { Incidence rate } \\
\qquad(95 \% \mathrm{Cl})\end{array}$ & Cases & $\begin{array}{c}\text { Incidence rate } \\
\text { (95\% Cl) }\end{array}$ & Cases & $\begin{array}{l}\text { Incidence rate } \\
\qquad(95 \% \mathrm{Cl})\end{array}$ \\
\hline Brescia province & $1,177,365$ & 39 & $\begin{array}{c}33.1 \\
(23.6-45.3) \\
\end{array}$ & 50 & $\begin{array}{c}42.5 \\
(31.5-56.0) \\
\end{array}$ & 67 & $\begin{array}{c}56.9 \\
(44.1-72.3) \\
\end{array}$ & 143 & $\begin{array}{c}121.5 \\
(102.4-143.1)\end{array}$ \\
\hline $\begin{array}{l}\text { Seven municipalities } \\
\text { along Chiese river }\end{array}$ & 57,009 & 0 & $\begin{array}{c}0 \\
(0-64.7) \\
\end{array}$ & 3 & $\begin{array}{c}52.6 \\
(19.9-153.8) \\
\end{array}$ & 2 & $\begin{array}{c}35.1 \\
(4.2-126.7) \\
\end{array}$ & 39 & $\begin{array}{c}684.1 \\
(486.5-935.1) \\
\end{array}$ \\
\hline $\begin{array}{l}\text { Remaining } \\
\text { municipalities }\end{array}$ & $1,120,356$ & 39 & $\begin{array}{c}34.8 \\
(24.8-47.6)\end{array}$ & 47 & $\begin{array}{c}42.0 \\
(30.8-55.8)\end{array}$ & 65 & $\begin{array}{c}58.0 \\
(44.8-63.9)\end{array}$ & 104.0 & $\begin{array}{c}92.8 \\
(75.8-112.5)\end{array}$ \\
\hline
\end{tabular}

$\mathrm{Cl}$ : confidence interval.

a Incidence rates are presented per 1,000,000 inhabitants.

LD diagnosis is primarily based on the detection of urinary antigen and most of the commercially available tests are specifically designed to diagnose infections caused by $L p 1$. Thus, they are poorly sensitive in detecting infections caused by non-Lp1 strains [16]. For this reason, cases of LD caused by non-Lp1 serogroups or by $L$. non-pneumophila often remain undetected [17]. Although the detection of Legionella spp. nucleic acid in respiratory secretions, lung tissue or any normally sterile site defines a probable case according to the EU case definition, PCR has been successfully introduced in several countries as a routine diagnostic method and the number of reported LD cases has markedly increased [18-20]. This is consistent with the high sensitivity and specificity of PCR to detect all $L p$ serogroups and $L$. non-pneumophila species in respiratory samples [21,22]. As the majority of $L p$ infections are caused by $L p 1$ strains, a real-time $P C R$ assay has been validated by the European Society of Clinical Microbiology and Infectious Diseases Study Group for Legionella Infections with the aim of accurate detection in clinical specimens [21]. The assay is designed to simultaneously detect $L p$ serogoups $1-15$ by targeting the mip gene, and the $L p 1$ serogroup specifically by targeting the wzm gene. Thus, this multiplexed assay allows us to recognise all $L p$ serogroups and distinguish $L p 1$.

\section{Outbreak detection}

In 2018, between the end of August and the first 2 weeks of October, a sudden increase of LD cases was reported in Brescia province, most notably in seven municipalities located along the Chiese river. Within the first few days of September, the Agency for Health Protection of the Brescia province was notified of 665 pneumonia cases requiring hospitalisation. Cases were immediately tested for Legionella by urinary antigen test (UAT), which gave negative results in more than $90 \%$ of cases. Only after real-time PCR was performed on respiratory secretions of UAT-negative cases was $L$. pneumophila detected. When respiratory secretions were available, culture examination was also requested. Immediately, a multidisciplinary team, which consisted of public health professionals, epidemiologists, medical doctors and microbiologists, was established to conduct epidemiological and environmental investigations to identify the source of the outbreak and to adopt the needed control measures. The objective of our report is to describe epidemiological, environmental and microbiological investigations and report factors that contributed to the outbreak.

\section{Methods}

\section{Epidemiological investigation}

The first LD case was detected 30 August 2018. The epidemiological investigation started few days later, on the first day of September and lasted until 18 October 2018. Since Legionella was the pathogen most suspected to cause the outbreak, an outbreak case definition was formulated to distinguish LD from pneumonia of a different origin. A case of LD was included in the outbreak if they resided in Brescia province, presented with clinical symptoms of pneumonia and had laboratory confirmation for Legionella with at least one diagnostic test, according to the EU case definition [15].

Nosocomial and travel-related LD cases were excluded. Case finding included mandatory notifications and requests for information to local health authorities, general practitioners and hospitals present in the area. General practitioners and hospital physicians were informed of the ongoing outbreak and were asked to test all pneumonia cases for Legionella in order to enhance surveillance.

Cases were required to answer a standardised questionnaire addressing health conditions (presence of chronic diseases, smoking and alcohol habits, corticosteroids therapy and/or chemotherapy), places visited and routes travelled within their town vicinity, as 


\section{FIGURE}

Epidemic curve of Legionnaires' disease cases by date of symptom onset in residents of seven municipalities along the Chiese river, Brescia province, Italy, August-October $2018(\mathrm{n}=33)$

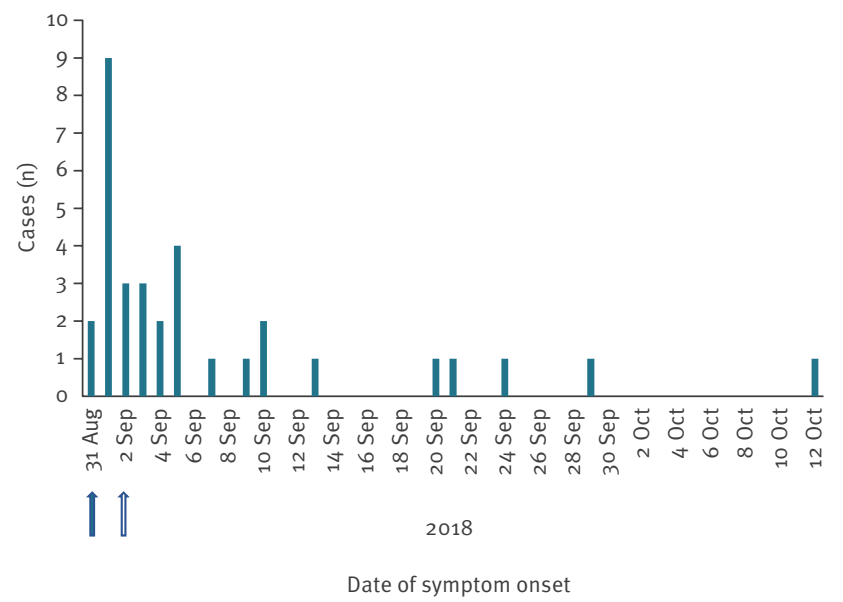

Number of cases is reported on the date of symptoms onset. The solid blue arrow indicates the index case of the outbreak. The open blue arrow indicates the start of active case finding.

well as usual social activities. The cases were mapped using a geographic information system to detect spatial movement patterns .

\section{Microbiological analysis of clinical samples}

Following the alert that the increase in pneumonia cases was attributable to Legionella infection, medical staff of all hospitals in Brescia province were asked to collect urine, respiratory secretions and sera from all cases admitted with pneumonia in order to test for LD. UAT (Legionella K-SeT, Coris Bioconcept, Gembloux, Belgium), culture of respiratory secretions or pulmonary tissues, real-time PCR and serology were used to diagnose cases.

Culture examination was carried out using agar plates with buffered charcoal yeast extract (BCYE-a; Thermo Fisher Scientific, Altrincham, United Kingdom (UK)) and selective antibiotic medium Modified Wadowsky-Yee (MWY) with BCYE growth supplement (Thermo Fisher). As a first screen, respiratory secretions were analysed using the FTD atypical CAP kit (Fast Track Diagnostics, Luxembourg), a multiplex real-time PCR for detection of L. pneumophila/L. longbeachae, Mycoplasma pneumoniae, and Chlamydophila pneumoniae. Subsequently, real-time PCR on respiratory secretions and lung biopsy fragments was also performed using primers and probes for the wzm gene specific for $L p 1$, and the mip gene, which recognises all $L p$ serogroups, as previously described [21]. In addition, nested sequence-based typing (SBT) was directly applied to real-time $P C R$ positive respiratory samples, according to the protocol previously described [22]. Serology was performed using an indirect immunofluorescence assay commercial kit (Bios GmbH, Munich, Germany). A positive single high titre serum was determined by microscopy when fluorescence (level of $1+$ to $3+$ ) was observed compared with a negative control; seroconversion was established when an increased level of fluorescence $\left(3^{+}\right)$was detected in the convalescent serum compared with the serum collected in the acute phase of the disease.

Although single high titre for non- $L p 1$ serogroups is not a sufficient criterion for defining an LD case according to the EU case definition, based on epidemiological considerations, we decided to include five pneumonia cases in the outbreak diagnosed by a single high titre.

\section{Microbiological analysis of environmental samples}

To identify the source of infection, the local health personnel inspected a large number of possible sources located in the Brescia province, particularly in the municipalities located along the Chiese river. Water samples (1L) were collected from drinking water taps of cases' homes, shopping centres, healthcare facilities, business and public buildings, from basin and circulating water of cooling towers of industrial sites and from wells and pipes of the municipal water network. The Chiese river and its irrigation canals that were adjacent to the municipalities where the most of cases occurred were also sampled. Water sample culturing was performed according to International Organization for Standardization (ISO) 11731:2017, using a detection limit of 100 colony-forming units ((CFU)/L) [23]. Legionella colonies isolated from both clinical and environmental samples were identified by latex agglutination test (Oxoid, Thermo Fisher Scientific). Serogroups of $L$. pneumophila were determined using monoclonal antibodies specific for each $L p$ serogroup (provided by the Medical Faculty, Institute of Medical Microbiology and Hygiene, Technical University Dresden, Dresden, Germany). Genotyping by SBT was used to identify the sequence type (ST) [24] and $L p 1$ colonies were sub-grouped by monoclonal antibodies, according to the Dresden panel [25].

\section{Ethical statement}

Ethical approval for the study was not necessary because the data used were collected as part of the infectious disease surveillance programmes defined by national legislation.

\section{Results}

\section{Epidemiological investigation}

Between 30 August and 18 October 2018, we detected 88 LD cases residing in the Brescia local health unit territory who were identified with at least one positive diagnostic test (UAT, culture, real-time PCR, or serology (seroconversion or single high titre)). Epidemiological investigation showed that the median age of cases was 60.6 years (range: $19-91$ ), the ratio of men/women was 


\section{TABLE 2}

Comparison of outbreak vs non-outbreak cases of

Legionnaires' disease, Brescia province, Italy, August-

October `2018 $(\mathrm{n}=88)$

\begin{tabular}{|l|c|c|} 
Characteristics & $\begin{array}{c}\text { Outbreak } \\
\text { cases } \\
\mathrm{n}=33\end{array}$ & $\begin{array}{c}\text { Non- } \\
\text { outbreak } \\
\text { cases } \\
\mathrm{n}=55\end{array}$ \\
\hline Age in years (mean; range) & $66.4(43-89)$ & $57.1(26-93)$ \\
\hline Men/women (ratio) & $23 / 10(2.3: 1)$ & $39 / 16(2.4: 1)$ \\
\hline Laboratory diagnosis & 0 & 25 \\
\hline Urinary antigen test & 24 & 30 \\
\hline Real-time PCR & 3 & 0 \\
\hline Culture & 1 & 0 \\
\hline Seroconversion & 5 & 0 \\
\hline Single high titre & 13 & 17 \\
\hline Underlying medical conditions & \multicolumn{2}{|l|}{} \\
\hline
\end{tabular}

2.4:1 (62/26), and 35\% of cases (31/88) had risks factors, such as diabetes, cardiopathy, or chronic, or autoimmune or immunosuppressive diseases. Comparing LD incidence in 2018, disaggregated by municipality of residence within the province, with the same period in 2015-17, a significant increase in the incidence rate was observed in seven municipalities located along the Chiese river, an area with a total population of 57,000 inhabitants (Table 1).

In these seven municipalities in 2018, LD incidence rate had increased nearly 20 times compared with the previous year (684.1/1,000,000 vs 35.1/1,000,000 inhabitants). In the remaining municipalities, incidence only increased by 1.5 times (92.8/1,000,000 in 2018 vs $58.0 / 1,000,000$ in 2017). This comparison therefore confirmed that the suspected LD outbreak involved only these seven municipalities.

During the study period, 33 cases were diagnosed among the residents living along the Chiese river. The remaining 55 cases detected in the study period lived in other municipalities in the Brescia province and represented the number of sporadic cases reported annually by this province, shown by an LD incidence rate of 121.5/1,000,000 in 2018 compared with 56.9/1,000,000 inhabitants in 2017 (Table 1). For this reason, they were not considered part of the outbreak.

According to the epidemic curve, the outbreak occurred between the end of August and the first half of October 2018 (Figure 1). All 33 cases required hospitalisation and two cases died.

When we analysed the cases residing in the seven municipalities and those residing in the rest of the province separately, we found differences in the epidemiological characteristics (Table 2). The most remarkable difference was that the UAT was negative in all 33 cases residing in the municipalities located along the Chiese river.

\section{Laboratory investigation of clinical and environmental samples}

Diagnostic tests were performed on the 33 LD cases included in the outbreak. For 3 cases, L. pneumophila colonies were isolated by culture of respiratory samples, identified to be L. pneumophila serogroup 2 (Lp2); two were also positive by real-time PCR. In 24 cases, at least one of the two real-time PCR assays was positive; in 15 of these, the real-time PCR test distinguishing $L p$ 1-15 serogroups from $L p 1$ provided the presence of $L p 2-15$ DNA (Table 3). The two cases who died had respiratory secretions that were positive by real-time $P C R$, while lung biopsy fragments were negative for both real-time PCR and culture.

Serology demonstrated seroconversion in one case and a single high titre in five cases, all for non-serogroup 1 L. pneumophila. Thus, according to the EU case definition, of the 33 LD cases, three were confirmed and 25 were probable cases. The remaining five cases, diagnosed by single high titre, were included in the outbreak based on epidemiological considerations. The $L p 2$ clinical isolates were typed as ST1455. In three additional cases that were positive for $L p 2-15$ by realtime PCR, nested-SBT provided allelic profiles highly similar to ST1455, lacking only one or two alleles. For Case 16, the allelic profile lacked three alleles, and had a difference in the proA locus (i.e. for proA 9 instead of 1) (Table 3).

From the beginning of September to the end of the outbreak (18 October 2018), 533 water samples were collected and analysed by culture; only 34 (6.4) were positive for $L p$ at a concentration ranging between 400 and 10,000 CFU/L (Table 4).

Ten cases' homes, and seven samples collected along the Chiese river and its irrigation canals were found contaminated by $L p$ non-serogroup 1 (Table 4 ). A minimum of five $L p$ colonies per sampling site were typed to determine serogroup and two colonies to determine the ST (Table 4). Seven of 14 water samples collected from the Chiese river were positive for $L p 2$. For each of these positive samples, five colonies were tested for serogroup and two were typed by SBT. Among the colonies of L. pneumophila serogroup 2, ST1455 was detected in three different samples while the others were ST80. Three industrial cooling towers were contaminated with $L p$ serogroups 1 and 6 (up to 10,000 CFU/L), underscoring the risk of bacterium proliferation and transmission without proper treatment and maintenance.

\section{Outbreak control measures}

Prevention and control actions were implemented following a notice of the increase and were aimed at significantly reducing the risk of contracting the disease. The following interventions were adopted: (i) citizens 


\section{TABLE 3}

Diagnosis and typing of clinical samples from Legionnaires' disease cases residing along the Chiese river, Brescia province, Italy, August-October $2018(\mathrm{n}=33)$

\begin{tabular}{|c|c|c|c|c|c|c|c|}
\hline Case & $\begin{array}{l}\text { Municipality of residence } \\
\text { along Chiese river }\end{array}$ & UAT & Culture & Real-time PCR & $\begin{array}{c}\text { Real-time } \\
\text { PCR } L p 2-15^{\mathrm{b}}\end{array}$ & SBT/Nested-SBT & Serology \\
\hline 1 & $\mathrm{~A}$ & $\mathrm{~N}$ & $\mathrm{~N}$ & $\mathrm{P}$ & $\mathrm{P}$ & No amp. & \\
\hline 2 & A & $\mathrm{N}$ & $\mathrm{N}$ & $\mathrm{P}$ & ND & No amp. & \\
\hline 3 & $B$ & $\mathrm{~N}$ & $\mathrm{~N}$ & $\mathrm{~N}$ & ND & No amp. & HT \\
\hline 4 & $\mathrm{~B}$ & $\mathrm{~N}$ & $\mathrm{~N}$ & $\mathrm{P}$ & ND & No amp. & \\
\hline 5 & $\mathrm{C}$ & $\mathrm{N}$ & $\mathrm{P}$ & $\mathrm{N}$ & $\mathrm{P}$ & $3,5,1,7,14,9,50(1455)$ & \\
\hline 6 & $\mathrm{C}$ & $\mathrm{N}$ & $\mathrm{N}$ & $\mathrm{N}$ & $\mathrm{P}$ & $3,5,0,7,0,9,50(1455 ?)$ & \\
\hline 7 & $\mathrm{C}$ & $\mathrm{N}$ & $\mathrm{N}$ & $\mathrm{P}$ & $\mathrm{P}$ & No amp. & \\
\hline 8 & $\mathrm{C}$ & $\mathrm{N}$ & $\mathrm{N}$ & $\mathrm{P}$ & $\mathrm{P}$ & No amp. & \\
\hline 9 & $\mathrm{C}$ & $\mathrm{N}$ & $\mathrm{N}$ & $\mathrm{N}$ & ND & No amp. & $\mathrm{SC}$ \\
\hline 10 & $\mathrm{C}$ & $\mathrm{N}$ & $\mathrm{N}$ & $\mathrm{N}$ & $\mathrm{P}$ & No amp. & \\
\hline 11 & $\mathrm{C}$ & $\mathrm{N}$ & $\mathrm{N}$ & $\mathrm{P}$ & ND & No amp. & \\
\hline 12 & $\mathrm{C}$ & $\mathrm{N}$ & $\mathrm{N}$ & $\mathrm{P}$ & ND & No amp. & \\
\hline 13 & $\mathrm{D}$ & $\mathrm{N}$ & $\mathrm{N}$ & $\mathrm{P}$ & ND & No amp. & \\
\hline 14 & $\mathrm{E}$ & $\mathrm{N}$ & $\mathrm{N}$ & $\mathrm{P}$ & $\mathrm{P}$ & No amp. & \\
\hline 15 & $\mathrm{E}$ & $\mathrm{N}$ & $\mathrm{N}$ & $\mathrm{P}$ & $\mathrm{P}$ & $3,5,1,7,0,9,50(1455 ?)$ & \\
\hline 16 & $\mathrm{E}$ & $\mathrm{N}$ & $\mathrm{N}$ & $\mathrm{P}$ & $\mathrm{P}$ & $3,0,-1,0,14,1,50$ & \\
\hline 17 & $\mathrm{E}$ & $\mathrm{N}$ & $\mathrm{N}$ & $\mathrm{P}$ & $\mathrm{P}$ & No amp. & \\
\hline 18 & $\mathrm{E}$ & $\mathrm{N}$ & $\mathrm{N}$ & $P$ & $P$ & No amp. & \\
\hline 19 & E & $\mathrm{N}$ & $\mathrm{N}$ & $P$ & $P$ & No amp. & \\
\hline 20 & $E$ & $\mathrm{~N}$ & $\mathrm{~N}$ & $\mathrm{P}$ & $\mathrm{P}$ & No amp. & \\
\hline 21 & $\mathrm{E}$ & $\mathrm{N}$ & $\mathrm{N}$ & $\mathrm{P}$ & $P$ & $3,5,1,7,0,9,50(1455 ?)$ & \\
\hline 22 & $E$ & $\mathrm{~N}$ & $\mathrm{~N}$ & $\mathrm{~N}$ & ND & No amp. & HT \\
\hline 23 & $\mathrm{E}$ & $\mathrm{N}$ & $\mathrm{N}$ & $\mathrm{N}$ & ND & No amp. & HT \\
\hline 24 & $E$ & $\mathrm{~N}$ & $\mathrm{~N}$ & $\mathrm{~N}$ & ND & No amp. & HT \\
\hline 25 & $E$ & $\mathrm{~N}$ & $\mathrm{~N}$ & $P$ & ND & No amp. & \\
\hline 26 & $E$ & $\mathrm{~N}$ & $\mathrm{~N}$ & $\mathrm{P}$ & ND & No amp. & \\
\hline 27 & $\mathrm{E}$ & $\mathrm{N}$ & $\mathrm{N}$ & $P$ & ND & No amp. & \\
\hline 28 & $\mathrm{~F}$ & $\mathrm{~N}$ & $\mathrm{P}$ & $P$ & $P$ & $3,5,1,7,14,9,50(1455)$ & \\
\hline 29 & $\mathrm{~F}$ & $\mathrm{~N}$ & $\mathrm{~N}$ & $\mathrm{~N}$ & ND & No amp. & $\mathrm{HT}$ \\
\hline 30 & $\mathrm{~F}$ & $\mathrm{~N}$ & $\mathrm{~N}$ & $\mathrm{P}$ & ND & No amp. & \\
\hline 31 & $\mathrm{~F}$ & $\mathrm{~N}$ & $\mathrm{~N}$ & $\mathrm{P}$ & ND & No amp. & \\
\hline 32 & $\mathrm{~F}$ & $\mathrm{~N}$ & $\mathrm{~N}$ & $\mathrm{P}$ & ND & No amp. & \\
\hline 33 & G & $\mathrm{N}$ & $P$ & $\mathrm{~N}$ & ND & $3,5,1,7,14,9,50(1455)$ & \\
\hline
\end{tabular}

HT: single high titre; N: negative; ND: not determined; No amp.: no amplification: P: positive; SBT: sequence-based typing; SC: seroconversion; UAT: urinary antigen test.

a Real-time PCR was performed using a commercial kit, as denoted in Methods.

${ }^{\mathrm{b}}$ Real-time PCR was performed according to Mentasti et al. [21]. 
TABLE 4

Legionella pneumophila detection and typing from investigated sampling sites in seven municipalities along the Chiese river, Brescia province, Italy, August-October $2018(\mathrm{n}=533)$

\begin{tabular}{|c|c|c|c|c|c|}
\hline Sampling site & $\begin{array}{l}\text { Total samples } \\
\qquad(n=533)\end{array}$ & $\begin{array}{l}L p \text {-positive samples } \\
\qquad(\mathrm{n}=34)\end{array}$ & CFU/L range & Serogroup & ST \\
\hline Cases' homes & 262 & 12 & $400-6,500$ & $1,3,4,5,6,8,10$ & 1 \\
\hline Industrial wells & 54 & 2 & $3,000-4,500$ & 1 & 12 \\
\hline Industrial cooling towers & 102 & 10 & $400-10,000$ & 6,1 & $2737,2740,2741$ \\
\hline Chiese river & 14 & 7 & $2,000-8,000$ & 2 & 1455,80 \\
\hline Sporting and accommodation sites & 18 & 3 & 400 & 8 & ND \\
\hline Municipal water and wells & 83 & 0 & 0 & 0 & ND \\
\hline
\end{tabular}

CFU: colony-forming unit; L: litre; ND: not determined; ST: sequence type.

At least five L. pneumophila colonies of each sample were tested for serogroup. Two colonies were typed for ST.

residing in the outbreak area were informed of the best practices for Legionella control at home and asked to apply them, (ii) disinfection of all industrial and non-industrial plants that might give rise to aerosols was requested, (iii) a correct use of the Chiese river water was recommended, taking into account periods of drought and guaranteeing the minimum vital flow for the ecological balance of the river itself, (iv) European Legionnaires' disease Surveillance Network was promptly informed by email in order to identify LD cases among European citizens who had travelled in the epidemic area. From 18 October 2018, the incidence of LD cases returned to the level of the previous years, indicating that the epidemic was over and demonstrating the effectiveness of the control measures applied. One of the greatest points of criticism faced during the outbreak investigation was the detection of $L p 2$ in cooling towers, which highlighted the lack of a cooling tower register. As a result, the local health authority decided to enact a regional law aimed at implementing a mandatory notification of cooling towers, as recommended by the national Legionella guidelines [26].

\section{Discussion}

In Italy between August and October 2018, a LD outbreak consisting of 33 cases caused by Lp2 occurred in seven municipalities of the Brescia province located along the Chiese river. Indeed, all 33 cases were negative by UAT, and in three cases, cultureconfirmed Lp2 ST1455 was isolated. To the best of our knowledge, no $L p 2$ outbreaks have been reported thus far, only sporadic cases. In Germany in 2008 , a case associated with a hotel stay, caused by Lp2 ST39, has been described [27], while in Italy in 2016, Lp2 ST1455 was identified in a case with a community-acquired LD (data collected by the Italian national reference laboratory for Legionella). By querying the SBT database maintained by Public Health England's Bioinformatics Unit in November 2020 (Accessed via web archive: https://webarchive.nationalarchives.gov. uk/20190501130700/http://bioinformatics.phe.org. uk/legionella/legionella_sbt/php/sbt_homepage.php; new website under construction at time of publication), we found that ST1455 is poorly represented with only four strains: two from France, one from Switzerland and one from north-eastern Italy, isolated from a community-acquired LD case in 2016 in a region far from the current outbreak area.

In the outbreak described here, we used multiple diagnostic methods combined with a thorough epidemiological investigation to explore all possible common sources of infections, which provided great value in recognising the epidemic event. It is well-documented that no diagnostic test is $100 \%$ sensitive and specific and, although the UAT is easy and rapid to perform and highly sensitive for $L p 1$ infections, it has limited sensitivity for other $L p$ serogroups $[17,20,28-31]$. On the contrary, culture of respiratory secretions, which is the only method able to identify single $L p$ serogroups and non- $L p$ species, is seldom performed because of low sensitivity and the need for specific media and experienced microbiologists; further acquisition of respiratory secretions is complicated by the existence of a non-productive cough in LD cases [16]. For these reasons and the higher virulence of $L p 1$ compared with non-Lp1 serogroups, these strains represent only $9 \%$ of isolates stored at the national reference laboratory of Legionella and, in 2018, amounted to only ca $7.9 \%$ of the culture-confirmed LD cases notified in the EU/ European Economic Area (EEA) (personal communication, Lara Payne Hallström, ECDC, September, 2019). In this outbreak, the possibility to discriminate $L p 1$ cases from non- $L p 1$ cases by realtime PCR combined with the isolatation of $L p 2$ colonies by culture suggested that non- $L p 1$ serogroups were responsible for the epidemic event. Moreover, as already observed in other Legionella infections [22], nested-SBT was applied directly to respiratory samples. This method improved the diagnostic identification because it allowed the detection of three additional cases caused by ST1455 strains (six total infections). Therefore, fielding as many diagnostic and typing tools as possible in combination with epidemiological data is of great benefit in outbreak investigations, as demonstarated in this unusual LD outbreak. In particular, the use of real-time PCR has played an 
important role in identifying the majority of cases of this epidemic event, thereby providing strong justification for performing PCR in pneumonia cases requiring hospitalisation.

The detection of any species or serogroup of Legionella from lower respiratory secretions, lung tissue, pleural fluid or extrapulmonary site by a validated nucleic acid amplification test has been recently adopted by the Centers for Disease Control and Prevention in order to define a confirmed LD case [32]. According to the EU case definition, however, a case with a positive PCR test is only considered a probable LD case and, therefore, laboratories mainly adopt UAT despite the well-known limitations [15]. Therefore, we propose that the case definition of LD should be changed in the EU so that PCR can be used to define a confirmed case and that laboratories are encouraged to use this molecular method. We think this could increase the diagnosis of infection in cases which would otherwise remain underdiagnosed.

The timely collection of respiratory and environmental samples made it possible to find a unique match between the $L p 2$ isolates from clinical samples and environmental samples, specifically those from the water collected in the Chiese river and its irrigation canals, typed as ST1455. The natural occurrence of Legionella in freshwater systems is well documented [16]. However, with the exception of irrigation canals, we could not identify any process of water uptake from the river that was able to produce aerosol, nor was there any evidence that a source of infection (e.g. industrial drains) had contaminated the river. Of note, an LD outbreak linked to the Wester river and industrial drains was described in 2013 in Germany [33]. On this occasion, the epidemic strain found in water samples from the Wester river and its branches came from two cooling towers of different companies: a sewage pretreatment plant within the municipal water supply system and the city waste water treatment plants.

According to local informants, irrigation in the area affected by the outbreak mainly occurs through flooding of the cultivated land using water from irrigation canals. However, there was the suspicion that aerosolproducing sprinklers may had been used.

In the period preceding the first LD cases, the river water level was quite low because of high temperatures and low rainfall, meteorological conditions that could have favoured increased Legionella concentration in the river. Heavy thunderstorms occurred in the days immediately before the occurrence of the first cases, creating conditions which could have been favourable to the production and spread of infectious aerosols. Similar conditions were observed in an $L p$ outbreak that occurred in the same year between July and August in Lombardy region in the metropolitan area of Milan [34]. Although the area where the cases occurred has many industrial plants equipped with cooling systems, Lp2 ST1455 colonies were not detected in any of the sampled cooling towers. One explanation could be that news reports about the outbreak were spread through newspaper and social media channels from the beginning. This possibly allowed the owners of industrial plants potentially contaminated by Legionella to implement adequate disinfection measures so, by the time analysis was performed, the water samples showed negative results.

During the environmental investigation, our main obstacle in identifying the source(s) of infection was the lack of a register of cooling towers, which, although recommended in Italian guidelines for Legionella prevention and control since 2015 , has not been adopted by most municipalities.

In the absence of such a register in an affected area, we cannot excluded the possibility that additional, unknown cooling systems also exist and were not inspected. Therefore, the establishment of a cooling tower register was one of the main recommendations made to local and regional health authorities in order to facilitate future outbreak investigations.

In conclusion, in spite of the large amount of clinical and environmental samples analysed and in-depth epidemiological and environmental investigations, the source of infection of this unusual outbreak remains not clearly identified. Notwithstanding, the outbreak led to the establishment of a cooling tower register in the whole region, which marks an important public health policy change.

\section{Acknowledgements}

Health Protection Agency Metropolitan of Brescia Legionnaires' Disease Investigation Teams: Public health unit; Infectious diseases surveillance unit; Laboratory of prevention; Occupational health and prevention unit; Epidemiological unit.

\section{Conflict of interest}

None declared.

Authors' contributions

MS, MLR, MCR acquired the epidemiological and laboratory data, drafted the manuscript and discussed the results. MS, $A G$ and MLR performed analysis of clinical samples, identification and typing of isolated strains (both clinical and environmental). MGC helped to collect and elaborate epidemiological data. MM and AP collected the epidemiological data and coordinated the epidemiological and environmental investigations. GR, DC and MG contributed to the implementation and support of the coordination of epidemiological investigations of the outbreak. DB and CR performed the analysis of the environmental samples and first steps of dentification of Legionella. AC, CG and SC coordinated clinical laboratory activities, collected and analysed the clinical samples and carried out the first steps of identification of Legionella. 


\section{References}

1. Fraser DW, Tsai TR, Orenstein W, Parkin WE, Beecham HJ, Sharrar RG, et al. Legionnaires' disease: description of an epidemic of pneumonia. N Engl J Med. 1977;297(22):1189-97. https://doi.org/10.1056/NEJM197712012972201 PMID: 335244

2. Shivaji T, Sousa Pinto C, San-Bento A, Oliveira Serra LA, Valente J, Machado J, et al. A large community outbreak of Legionnaires disease in Vila Franca de Xira, Portugal, October to November 2014. Euro Surveill. 2014;19(50):20991. https:// doi.org/10.2807/1560-7917.ES2014.19.50.20991 PMID: 25597540

3. García-Fulgueiras A, Navarro C, Fenoll D, García J, GonzálezDiego P, Jiménez-Buñuales T, et al. Legionnaires' disease outbreak in Murcia, Spain. Emerg Infect Dis. 2003;9(8):915-21. https://doi.org/10.3201/eido908.030337 PMID: 12967487

4. Scaturro M, Fontana S, Crippa S, Caporali MG, Seyler T, Veschetti E, et al. An unusually long-lasting outbreak of community-acquired Legionnaires' disease, 2005-2008, Italy. Epidemiol Infect. 2015;143(11):2416-25. https://doi. org/10.1017/So950268814003094 PMID: 25427871

5. Mercante JW, Winchell JM. Current and emerging Legionella diagnostics for laboratory and outbreak investigations. Clin Microbiol Rev. 2015;28(1):95-133. https://doi.org/10.1128/ CMR.00029-14 PMID: 25567224

6. European Centre for Disease Prevention and Control (ECDC). Annual epidemiological report for 2018. Stockholm: ECDC; 2021. Available from: https://www.ecdc.europa.eu/sites/ default/files/documents/AER-legionnaires-2019.pdf

7. European Centre for Disease Prevention and Control (ECDC) Surveillance atlas of infectious disease. Stockholm: ECDC. [Accessed: 24 Mar 2021]. Available from: https://atlas.ecdc. europa.eu/public/index.aspx

8. Zanella MC, Yerly S, Cherkaoui A, Renzi G, Mamin A, Lourenço Cordes L, et al. A community outbreak of Legionnaires' disease in Geneva, Switzerland, June to September 2017. Swiss Med Wkly. 2018;148:w14687. https://doi.org/10.4414/ smw.2018.14687 PMID: 30552854

9. Byrne BG, McColm S, McElmurry SP, Kilgore PE, Sobeck J, Sadler R, et al. Prevalence of infection-competent serogroup 6 Legionella pneumophila within premise plumbing in southeast Michigan. MBio. 2018;9(1):eooo16-18. https://doi.org/10.1128/ mBio.00016-18 PMID: 29437918

10. Ito A, Ishida T, Washio Y, Yamazaki A, Tachibana H. Legionella pneumonia due to non-Legionella pneumophila serogroup 1: usefulness of the six-point scoring system. BMC Pulm Med. 2017;17(1):211. https://doi.org/10.1186/s12890-017-0559-3 PMID: 29246145

11. Grottola A, Forghieri F, Meacci M, Fabio A, Pozzi L, Marchegiano P, et al. Severe pneumonia caused by Legionella pneumophila serogroup 11, Italy. Emerg Infect Dis. 2012;18(11):1911-3. https://doi.org/10.3201/eid1811.120216 PMID: 23092583

12. Nishizuka M, Suzuki H, Ara T, Watanabe M, Morita M, Sato C, et al. A case of pneumonia caused by Legionella pneumophila serogroup 12 and treated successfully with imipenem. J Infect Chemother. 2014;20(6):390-3. https://doi.org/10.1016/j. jiac.2014.01.010 PMID: 24629522

13. Amemura-Maekawa J, Kura F, Chida K, Ohya H, Kanatani J, Isobe J, et al. , Working Group for Legionella in Japan. Legionella pneumophila and other legionella species isolated from legionellosis patients in Japan between 2008 and 2016. Appl Environ Microbiol. 2018;84(18):e00721-18. https://doi. org/10.1128/AEM.00721-18 PMID: 29980559

14. Fontana S, Scaturro M, Rota MC, Caporali MG, Ricci ML. Molecular typing of Legionella pneumophila serogroup 1 clinical strains isolated in Italy. Int J Med Microbiol. 2014;304(5-6):597-602. https://doi.org/10.1016/j. ijmm.2014.04.004 PMID: 24881962

15. European commission (EC). Commission implementing decision (EU) $2018 / 945$ of 22 June 2018 on the communicable diseases and related special health issues to be covered by epidemiological surveillance as well as relevant case definitions. Brussels: EC; 2018. Available from: https://eur-lex. europa.eu/legal-content/EN/TXT/PDF/?uri=CELEX:32018Do945 $\&$ from $=E N \#$ page $=26$

16. Phin N, Parry-Ford F, Harrison T, Stagg HR, Zhang N, Kumar K, et al. Epidemiology and clinical management of Legionnaires disease. Lancet Infect Dis. 2014;14(10):1011-21. https://doi. org/10.1016/S1473-3099(14)70713-3 PMID: 24970283

17. Svarrer CW, Lück C, Elverdal PL, Uldum SA. Immunochromatic kits Xpect Legionella and BinaxNOW Legionella for detection of Legionella pneumophila urinary antigen have low sensitivities for the diagnosis of Legionnaires' disease. J Med Microbiol. 2012;61(Pt 2):213-7. https://doi.org/10.1099/jmm.0.035014-0 PMID: 21921112
18. Murdoch DR, Podmore RG, Anderson TP, Barratt K, Maze MJ, French KE, et al. Impact of routine systematic polymerase chain reaction testing on case finding for Legionnaires' disease: a pre-post comparison study. Clin Infect Dis. 2013;57(9):1275-81. https://doi.org/10.1093/cid/cit504 PMID: 23899682

19. Cristovam E, Almeida D, Caldeira D, Ferreira JJ, Marques T. Accuracy of diagnostic tests for Legionnaires' disease: a systematic review. J Med Microbiol. 2017;66(4):485-9. https:// doi.org/10.1099/jmm.0.000454 PMID: 28463665

20. Ricci ML, Grottola A, Fregni Serpini G, Bella A, Rota MC, Frascaro F, et al. Improvement of Legionnaires' disease diagnosis using real-time PCR assay: a retrospective analysis, Italy, 2010 to 2015. Euro Surveill. 2018;23(50). https:// doi.org/10.2807/1560-7917.ES.2018.23.50.1800032 PMID: 30563592

21. Mentasti M, Kese D, Echahidi F, Uldum SA, Afshar B, David $S$, et al. Design and validation of a qPCR assay for accurate detection and initial serogrouping of Legionella pneumophila in clinical specimens by the ESCMID Study Group for Legionella Infections (ESGLI). Eur J Clin Microbiol Infect Dis. 2015;34(7):1387-93. https://doi.org/10.1007/s10096-015-23634 PMID: 25851812

22. Scaturro M, Fontana S, Ricci ML. Use of nested polymerase chain reaction based on sequence-based typing of clinical samples to determine the source of infection for hospitalacquired Legionnaires' disease. Infect Control Hosp Epidemiol. 2011;32(5):510-2. https://doi.org/10.1086/659785 PMID: 21515984

23. International organization for standardization (ISO). ISO 11731. Water quality-enumeration of Legionella. Geneva: ISO; 2017. Available from: https://www.iso.org/standard/61782.html

24. Gaia V, Fry NK, Afshar B, Lück PC, Meugnier H, Etienne J, et al. Consensus sequence-based scheme for epidemiological typing of clinical and environmental isolates of Legionella pneumophila. J Clin Microbiol. 2005;43(5):2047-52. https:// doi.org/10.1128/JCM.43.5.2047-2052.2005 PMID: 15872220

25. Helbig JH, Bernander S, Castellani Pastoris M, Etienne J, Gaia V, Lauwers S, et al. Pan-European study on culture-proven Legionnaires' disease: distribution of Legionella pneumophila serogroups and monoclonal subgroups. Eur J Clin Microbiol Infect Dis. 2002;21(10):710-6. https://doi.org/10.1007/s10096002-0820-3 PMID: 12415469

26. Ministero della Salute. Linee guida per la prevenzione e il controllo della legionellosi. [Guidelines for prevention and the control of legionellosis]. Roma: Ministero della Salute; 2015. Italian. Available from: http://www.salute.gov.it/imgs/C_17_ pubblicazioni_2362_allegato.pdf

27. Lück PC, Hahn F, Senger M, Boers SA, Brandsema P. European network cooperation to identify hotel as source for pneumonia caused by Legionella pneumophila serogroup 2. Euro Surveill. 2008;13(24):1-2. https://doi.org/10.2807/ese.13.24.18903-en PMID: 18761945

28. Como J, Moffa MA, Bhanot N, Min Z, Cole KS, Kuzyck J, et al. Potential false-positive urine Legionella enzyme immunoassay test results. Eur J Clin Microbiol Infect Dis. 2019;38(7):1377-82. https://doi.org/10.1007/s10096-019-03575-2 PMID: 31119574

29. Rota MC, Fontana S, Montaño-Remacha C, Scaturro M, Caporali MG, Vullo V, et al. Legionnaires' disease pseudoepidemic due to falsely positive urine antigen test results. J Clin Microbiol. 2014;52(6):2279-80. https://doi.org/10.1128/JCM.00493-14 PMID: 24719437

30. Muyldermans A, Descheemaeker P, Boel A, Desmet S, Van Gasse N, Reynders M, National Expert Committee on Infectious Serology. What is the risk of missing legionellosis relying on urinary antigen testing solely? A retrospective Belgian multicenter study. Eur I Clin Microbiol Infect Dis. 2020;39(4):729-34. https://doi.org/10.1007/s10096-01903785-8 PMID: 31838606

31. Essig A, von Baum H, Gonser T, Haerter G, Lück C. Microbiological diagnosis and molecular typing of Legionella strains during an outbreak of legionellosis in Southern Germany. Int J Med Microbiol. 2016;306(2):109-14. https://doi. org/10.1016/j.ijmm.2016.01.001 PMID: 26868659

32. Centers for Disease Control and Prevention (CDC). Revision to the case definition for national Legionellosis surveillance. Atlanta: CDC. [Accessed: 24 Mar 2021]. Available from: https:// www.cdc.gov/legionella/health-depts/surv-reporting/casedefinitions.html

33. Petzold M, Ehricht R, Slickers P, Pleischl S, Brockmann A, Exner M, et al. Rapid genotyping of Legionella pneumophila serogroup 1 strains by a novel DNA microarray-based assay during the outbreak investigation in Warstein, Germany 2013. Int J Hyg Environ Health. 2017;220(4):673-8. https://doi. org/10.1016/j.ijheh.2016.02.004 PMID: 28501485

34. Faccini M, Russo AG, Bonini M, Tunesi S, Murtas R, Sandrini $M$, et al. Large community-acquired Legionnaires' disease outbreak caused by Legionella pneumophila serogroup 1, 
Italy, July to August 2018. Euro Surveill. 2020;25(20):1900523.

https://doi.org/10.2807/1560-7917.ES.2020.25.20.1900523

PMID: 32458793

\section{License, supplementary material and copyright}

This is an open-access article distributed under the terms of the Creative Commons Attribution (CC BY 4.0) Licence. You may share and adapt the material, but must give appropriate credit to the source, provide a link to the licence and indicate if changes were made.

Any supplementary material referenced in the article can be found in the online version.

This article is copyright of the authors or their affiliated institutions, 2021. 